\title{
Reflexive Modernization in the Era of Digital Economy
}

\author{
Sokolova N.G.* Troyanskaya A.I. Glavatskikh O.B.
}

\author{
Kalashnikov Izhevsk State Technical University, Izhevsk, Russia \\ *Corresponding author. Email: sokolova-ng@mail.ru
}

\begin{abstract}
Modern society is in unique conditions which are defined as the second modernity. The period after modernity turns the industrial society into the new, more reflexive network information society. It is characterized by the multiplicity of different types of knowledge and by risks for all the life-forms and people which are dependent of knowledge. Modern society is not only a society of knowledge but a society of risks. There is a position in modern publications regarding management of innovations and total digitization which shows the advantages of unprecedented economic benefit, an increase in production efficiency, which reflects aspects of techno-optimism and disadvantages of technological area and risks for ecosystem in terms of techno-pessimism. It is so called a "position either/or". It is necessary to provide the reflexive modernization which pays attention to the very process of modernization to form strategies of socio-economic development. The authors put forward theories of the reflexive modernization based on philosophy of techno-realism.
\end{abstract}

Keywords: reflexive modernization, reflexive modernity, techno-optimism, techno-pessimism, techno-realism,

digital economy, strategy of socio-economic development

\section{INTRODUCTION}

The risk society requires the reflexive modernization. The end of the 20th and the beginning of the 21st century are characterized by entering the information age known as "computer age" or "digital age". This is the period of a shift away from the industrial era to the information one. To date, the digital technologies are the actual reality of social life, the decisive factor of success and progress in each sphere of activity which gives the undeniable competitive advantage. The derived concepts such as digital ecosystem and digital economy have emerged with the development of the digital technologies and digital area [1].

However, the relevant conditions of human life can be indicated by the shocking epithet "the completion of modernity". According to E. Giddens, W. Beck and S. Lash [2], these conditions of the second modernity or postmodernity are opposed to an earlier version of modernity, and the problems posed by it cannot be solved by existing methods.

The postmodernity is distinguished by a new awareness of the risks that exist for all life-forms, plants, animals and humans which are created by the success in solving problems. Decisions that seemed to provide protection against the risks, both natural and social, are recognized as creating new anthropogenic risks as a by-product of their functioning [3]. There are completely new social dangers. Scientific achievements open up new areas, such as cloning or genetic modification; the decisions in these areas are taken without an adequate opportunity to assess the long-term consequences. Globally, the decisions themselves become a problem.
In modern specialized literature and in everyday life, there is the prevailing view on the total digitalization from the so-called "position either/or" which considers the possible advantages of an increase in the efficiency of the technological processes along with the disadvantages of the probable risks to human health and the ecosystem. Specialists in the field of the information technology and economics often tend to the pole of optimism with respect to the future, while specialists in the humanitarian fields and biologists gravitate to the pole of pessimism.

We come to the concept of the reflexive modernity which involves the reflexive modernization while determining the issue of choosing a conceptual direction in management in socio-economic systems: to force digitalization for the unprecedented economic benefits or to suspend it due to the significant risks to human health and even human existence [2]. The reflective modernization directs its attention to the modernization process itself. E. Giddens [4] noted that reflexivity was possible in any social system, and even globalized that topic with the concept of the reflexive modernity, arguing that society became more self-conscious, and therefore, reflective over time.

The reflexive modernization is the modernization process which characterizes the risk society where a progress is achieved through reorganizations, optimizations and changes. Science and technology in the form they are used for the reflexive modernization are connected not so much with the expansion of the resource base as with the reassessment of what is already used by society. Examples of the reflexive modernization are the precautionary principle and new social movements. 
The precautionary principle is a strategy for resolving potential harm in conditions when there is no extensive scientific knowledge on the issue at hand [4]. It emphasizes the need for suspension and balanced analysis before a transition to innovations that could be disastrous. Nevertheless, the use of rigorous formulation of the precautionary principle may block innovations, and technology that could be beneficial may be banned because of the potential opportunity of negative impacts, making its benefits unfulfilled.

Total digitalization challenges the very human essence. This situation is considered as the crisis of the subject. The opportunities of biotechnological improvement of a person calls into question its understanding as a stable entity or as a combination of stable properties. It is likely that the function of choice and decision-making will rest with artificially created algorithms (external to a person), which make decisions more efficiently than a person. The virtual environments, as stated by S. Khoruzhiy [5], lead a person to the "horizon of the existence", offering new alternative opportunities of life beyond the borders of the real being. Changes that occur with a person in new conditions under the influence of the technological environment, the opportunities of the virtual existence cause strong polar emotional reactions such as delight or, conversely, fear, and become the subject of evaluation by a person. These estimates can be illustrated by the poles of technooptimistic and techno-pessimistic perspectives of humans.

\section{RESULTS}

Techno-optimism as a philosophy of an unprecedented leap in productivity and techno-pessimism as a philosophy of subjectivity crisis.

Techno-optimism is revealed in the understanding of the technological progress as the main means of economic development, and informatization is considered as a condition for social integration, conflict-free and coordinated social actions [6].

Michio Kaku, futurologist [7], sets out the prospects of human as follows:

1. Physicists create the future today. This is the future of artificial intelligence, nanotechnology and biotechnology. Innovations in these technological areas will provide the wealth of the whole society in the near future.

2. At present, humanity is going through the postindustrial revolution in technology. In the post-industrial era, technological growth will be at least stable. It will put an end to the economic shortfall. It will become possible to print many things with the help of a 3D printer; it will only be necessary to download a virtual product model on the Internet.

3. The main resource of the economy of the new time is information. Only artificial intelligence, which exists in the form of three main types: robots, pattern recognition programs, and machine learning, can process more information.

4. People will need a fundamentally new permanent access to the Internet to effectively interact with this world. This will affect all aspects of learning. Memorization is no longer required: education will be less and less dependent on memory. An infinite amount of knowledge will be available to everyone. Professors will stop teaching and turn into mentors who guide students in their careers and give advice in such a learning system.

Techno-optimists are convinced that the picture of events will have nothing to do with the plot of the movie "Terminator", in which robots tried to destroy the human race. Human and artificial intelligence will integrate with each other to achieve more amazing innovations in the future.

Technological ways of enhancing intelligence are proposed. Programs can help in the struggle against laziness, helping to correctly develop aims and strategy in general, using the GTD (Getting Things Done) as the selforganization methodology [8]. Devices provide more correct processing of large amounts of information. Builtin memory will help people with attention deficit disorder. Company-developers are interested in the ability of neuromorphic chips to turn smartphones and other mobile devices into cognitive companions that will pay attention to users' actions and learn their habits. According to S. Kumar, if a person and a device perceive the environment in the same way, this device will better understand the person's intentions and desires [9].

In a broad sense, all human interactions with technology can be considered as cyborgization. Some anthropologists, for example, E. Case, tend to a broad understanding of the cyborg and even claim that people are already cyborgs because their daily life is very closely connected with technology [10]. E. Musk claims that the only chance to preserve the human species is to merge with artificial intelligence [11]. There is already the aim for humanity to preserve the species.

Techno-pessimism presents the other side.

1. Informatization of society is fraught with the establishment of sophisticated forms of sanctions and restrictions; it opens up the opportunity of the total tracking and control system by the state, as well as supranational corporations.

2. People will lose their economic and military usefulness, with the result that the political and economic system will cease to cherish them.

3. The system will no longer need individuality. Technological tools will understand people better than they understand themselves, and make most important decisions for them. People will lose their rights and freedom. If an artificial algorithm makes fewer mistakes than a person, there is a reason to trust it to decide more and more. This situation identifies the separation of intelligence from consciousness.

We can give an example of the research undertaken by Facebook, which shows that the algorithm understands mood of people better than their friends, parents and spouses. Volunteers answered one hundred questions of the questionnaire. The algorithm predicted their answers based on the analysis of "likes" - pages, images that they marked as liked. The accuracy of the predictions depended on the number of likes. It only took 10 likes for the 
algorithm to exceed the accuracy of the predictions of colleagues, it took seventy likes to surpass friends, and three hundred likes to surpass spouses [10].

4. The formation of a new digital disparity will limit the ability of people to take an active part in social life by their access to the cutting-edge technologies and the Internet (digital barrier, access problem). This will lead to the establishment of the technological hierarchy. Only the new elite of improved superhuman who can bring new things to the technological development will be considered as promising. This division of society will lead to the collapse of the labor market.

Involvement of technologies in almost all life processes is connected with specific manifestations of technophobia. It is about internal resistance and even fear of the new technology. When a person understands that he/she cannot avoid a contact with the new technologies, a feeling of control loss manifests itself [12]. Technophobia is distributed to older people and people who are less educated. Individualistic societies are less susceptible to technophobia because people are more interested in experiment. Fear of technology is more characteristic of societies where people try to avoid uncertainty, where people feel more comfortable in the conditions of given rules and instructions. It is worth noting that the avoidance of uncertainty is at a high level in Russia [12, 13].

The worldview position and society vision of the future are important in shaping the attitude to the technological innovation. Now there is a complicated attitude to innovation in Russia: techno-optimism combined with catastrophic social pessimism is widespread [12]. People are interested in technologies up to a point. Invasive technologies of expanding the mental and physical capabilities of a person, neural interfaces, editing the genome of an unborn child are negatively perceived. People are afraid to realize that the technologies will make decisions for them, without their participation and awareness.

Society goes through a stage of "shock" with understanding of the inevitable technological changes. Mistakes occur until a person realizes a new technology as a solution to a social or personal problem, until it is not determined who is able to support in case of difficulties, and with whom it is necessary to agree on the rules governing the use of technology. Significant challenges in predicting social consequences have emerged while assessing the consequences of introducing technology into socio-economic systems. There is no methodology of predicting exactly how the new technology will change social interactions [14].

\section{CONCLUSION}

The concept of techno-realism as a result of the reflection of antagonistic approaches. Creating a super-intellectual society is the aim of a comprehensive strategy for socioeconomic development and the way of the reflective modernization.
A comparison of the opportunities and risks of technooptimistic and techno-pessimistic prospects leads to the conclusion that a reflexive approach to modernization is necessary. The time of new anthropology encourages humanity to develop a meaningful attitude to the introduction of the technological innovations. The development of the critical thinking abilities and a person's ability to navigate in the environment saturated with information based on reflection becomes important $[15,16]$.

The balanced analysis of techno-optimistic and technopessimistic perspectives $[7,10,11,12]$ has given expression to the idea of techno-realism [17]. The philosophy of techno-realism served as the basis for the authors to formulate the following basic principles on which the reflective modernization should be carried out:

1. It is necessary to be aware of how technology affects people's values. Technologies affects the way people work, decision making, preferences. These technologies cannot be neutral, they always involve the assimilation of certain social and economic ideas that form a person's specific view of the world.

2. The Internet fully reflects society in all its diversity. On the one hand, it can be a means of enlightenment and development; on the other hand, it reproduces the painful, perverted, or banal manifestations of the human essence.

3 . The state will play an important role in the electronic community. Cyberspace cannot be considered as a special zone of jurisdiction independent of all official institutions. The state is obliged to respect the rules adopted in cyberspace, and should not impede the progress of this new cultural world with the help of censorship. But the state can take care of the integration and security of the "virtual" community by controlling the behavior of individual citizens and corporations while realizing its role as a guarantor of the democratic values.

4. It is unacceptable to substitute the ability to process and transmit information with the more difficult task of turning it into knowledge and wisdom. Computers cannot replace person's cognitive abilities, perceptions, thinking and evaluating. The velocity, low cost and availability of information pose a new challenge to the human mind and skepticism.

5. The development of the moral conscience in the digital society should be a priority. It is extremely important to pay more attention to the formation of the children's value-ideological sphere, that is to implement it along with (or earlier) their inclusion in the modern information environment, in the process of socialization in the family and at school, to develop their moral conscience before the ability to use technology manifests itself. Hypertextuality and multitasking contribute to the process of sustained attention destruction of network users down to attention deficit. The focus on the constantly accessible, objective information leads to a change of its memorization, which is increasingly fulfilling due to the "external expansion" of consciousness. The process of visualization of consciousness is activated, which can lead to a reducing the role of abstract logical thinking [19]. It must not be 
forgotten that human personality and thinking develops in activism and overcoming obstacles.

6 . The use of one of the key principles of the reflexive modernization known as the precautionary principle, is distributed unevenly across the regions because of their uneven innovative development. The peripheral regions need the advanced development of infrastructure and active digitalization to overcome the digital barrier, reequipping production, educational, medical institutions, training the population in the skills of using new technologies. The regions of the "front-line" of introducing technologies which become a source of innovation need to focus on techno-realism and the selection of innovations according to the criterion of their social usefulness. The use of the precautionary principle is not evenly distributed across the regions. The precautionary principle is ethically challenged because it can block the progress in the developing regions.

7. Information culture should become the necessary component of the civil system of education. Hardware and software become the powerful force in the social system. Participation in their creation and improvement must be considered as a part of the individual civil rights. The criteria for the selection of technological innovations should be set collectively in the process of the work of the respective collegiate bodies, committees, commissions of heterogeneous composition, that is, including representatives of different fields of knowledge, defining the positions of techno-optimism, techno-pessimism and techno-realism.

Forecasts regarding a future person inevitably become only a probabilistic model. The future cannot be predicted because technology is non-deterministic. Both technology and people have the ability to exert formative effects on each other. The same technology can lay the groundwork for the different social systems. There is the objective facing humanity to be more creative regarding the future, to begin thinking and acting in a new way to determine what probabilities materialize, having considered the wide range of opportunities.

This creative attitude can be expressed in the development strategies. For example, the strategy for creating the superintellectual society "The Society 5.0" with the participation of large business was developed by the government in Japan, a region of advanced technological development. In the framework of the strategy, all the new products and decisions are considered not just as things or technologies, but primarily as a contribution to the development and economic growth of the country. The transformation of the production sphere is considered in the context of public benefit. In Russia, the strategic direction of development is called the "digital economy", in Germany it is "The Industry 4.0", in the USA - "The Industrial Internet Consortium".

The aim of "The Society 5.0" is to create equal opportunities and provide the environment for the realization of each person's capacity. With the help of technology, it is necessary to remove the physical, administrative and social barriers to self-realization of a person. This should lead to the sustainable social and economic growth. It is supposed to consciously set the direction of the technological development and motivate large companies to create socially-oriented technologies, to develop those technologies which improve the quality of people life. Intelligent transport systems, personalized services, systems for transforming the production sphere can be understood in the context of public benefit; artificial intelligence (AI) and the Internet of things (IoT) technologies will become fully effective, and the social structure will become as intelligent as possible [18].

It is important to ask ourselves what will happen to society and to our daily life if we accept the statement that it is only data processing. The self-determination of a person, understood as the development of a relationship to the social environment and the objective world, the awareness of your place in it, is not connected with the Internet using [20]. Conscious modernity indicates the value of spiritual practice as human manifestations in a new way, offering an understanding of traditional human being as a separate form of being along with others (virtual being, unconscious, religious). That is, the virtual existence of a modern person does not cancel and should not cancel the direct interaction with the social, subject and natural environment.

The attention must be paid not only to the technical components, but also to developing communication strategies for the implementation of technologies during modernization. It is possible to agree on the rules for the use of technologies and predict the consequences of their implementation. It is important to start introducing new technologies not as a curiosity or an object of pride but as a means which will help a person address the problems, make the life better. Error protection systems must be developed for technologies, the use of which is fraught with risk, so that won't be harmful for a person while using them. The interface can warn a person about the need to be more attentive to the consequences of using the program.

Ultimately, the new technologies must not only meet the increasingly ambitious challenges of people, but also become the instrument of establishing a dialogue between them. It is time to develop social, legal, economic norms not only about who and under what conditions can access personal "big data" obtained from the analysis of "digital traces" that are constantly left everywhere while using smart devices, but also about rules which you need to follow using big data. The development of many technologies will depend on how people overcome social pessimism and distrust of social institutions in the coming decades. Society will really need humanitarian and social technologies which increase the ability to timely detect technological risks and agree on the rules of life in the digital economy [12].

The objective of the conscious technology using and the implementation of the reflexive modernization becomes extremely important. The importance of preserving the human essence and manifestations is recognized as the certain area of work.

To date, the use of digital technologies is in demand precisely for addressing urgent problems in Russia. The 
[10] Yu.N. Kharari Homo Deus. Kratkaya istoriya budushchego. M.: Sindbad, 2019. 496 s. the optimization of processes, but also by improving the quality of life of the population, directly depends on how jointly and harmoniously business community, government structures and social institutions will work on developing a strategy for socio-economic development. The development strategy of the digital economy should include the reflexive modernization, which pays its attention to the process of modernization itself, and be deployed based on the philosophy of techno-realism put forward by the authors. Under these conditions, its results may be positive in the future.

\section{REFERENCES}

[1] N.G. Sokolova, O.V. Titova, Digital marketing as a type: concept, tools and effects, Advances in Economics, Business and Management Research, volume 81 1st International Scientific Conference "Modern Management Trends and the Digital Economy: from Regional Development to Global Economic Growth" (MTDE 2019) C.509-513. DOI: 10.2991/mtde-19.2019.101, ISBN: 9789462527218.

[2] U. Bech, World at Risk, Cambridge: Polity Press, 2009. P. 126

[3] He C. Modernization Science, New York: Springer, 2012. P. 110-225.

[4] U. Beck, A. Giddens, S. Lash, Reflexive Modernization. Politics, Tradition and Aesthetics in the Modern Social Order. Stanford, CA: Stanford University Press, 1994. 228 p.

[5] S.S. Khoruzhiy, Ocherki sinergiynoy antropologii. M.: Institut filosofii, teologii i istorii sv. Fomy, 2005. $408 \mathrm{~s}$.

[6] T.B. Medvedeva, Tekhnologicheskaya utopiya i formy yeye reprezentatsii $\mathrm{v}$ sovremennoy kul'ture: tekhno-progressivizm, transgumanizm i tsifrovaya utopiya, Nauchnyye vedomosti Belgorodskogo gosudarstvennogo universiteta. Seriya: Filosofiya. Sotsiologiya. Pravo. 2011. №20(115). V. 18. S. 55-61.

[7] M. Kaku, Budushcheye razuma. M.: Al'pina Nonfikshn, 2015. $502 \mathrm{~s}$.

[8] Usileniye intellekta. http://transhuman.ru/usilenie-intellekta obrashcheniya: 12.02 .2020 )

[9] Neyromorfnyye chipy.

URL: http://www.atscomputers.ru/news/124-post24 obrashcheniya: 10.02 .2020$)$
[11] Ilon Mask i Dzhek Ma obsuzhdayut riski, svyazannyye $\mathrm{s}$ II. URL: https://maxpark.com/community/8223/content/6860286 (data obrashcheniya: 12.02.2020)

[12] Tekhnologicheskaya istoriya uzhasov: $\mathrm{v}$ chem prichiny poyavleniya strakha pered novymi razrabotkami. URL: https://news.itmo.ru/ru/news/7057/ (data obrashcheniya: 08.02.2020)

[13] A.I. Troyanskaya, Osobennosti organizatsionnoy kul'tury kak sostavlyayushchiye innovatsionnogo potentsiala predpriyatiy Udmurtskoy Respubliki, Vestnik Kostromskogo gosudarstvennogo universiteta. Seriya: Pedagogika. Psikhologiya. Sotsiokinetika. 2018. № 4. S. 126-131.

[14] A.L. Zhuravlev, T.A. Nestik, A.V. Yurevich, Prognoz razvitiya psikhologicheskoy nauki i praktiki $\mathrm{k}$ 2030 g., Psikhologicheskiy zhurnal. 2016. T. 37. №5. S. 45-64.

[15] A.I. Troyanskaya, Refleksiya kak osnova sposobnosti oriyentirovaniya $\mathrm{v}$ informatsionno nasyshchennoy srede, Psikhologiya sposobnostey: sovremennoye sostoyaniye i perspektivy issledovaniy. Materialy Vserossiyskoy nauchnoy konferentsii, posvyashchennoy 60-letiyu so dnya rozhdeniya V.N. Druzhinina. M.: IP RAN, 2015. S. 208-210.

[16] A.I. Troyanskaya, Kharakteristika instrumental'nogo stilya refleksii studentov tekhnicheskogo napravleniya podgotovki, Psikhologiya. Istoriko-kriticheskiye obzory i sovremennyye issledovaniya. 2019. T.8. № 4A. S. 180-186.

[17] E. Shapiro, Manifest tekhnorealizma. URL: www.technorealism.org (data obrashcheniya: 27.11.2019)

[18] Kh. Onoda Obshchestvo 5.0. URL: https://www.forbes.ru/partnerskie-materialy/367837obshchestvo-50-yaponskie-tehnologii-dlya-cifrovoytransformacii (data obrashcheniya: 20.11.2019)

[19] V.D. Yemel'yanenko, Internet i dukhovnyy mir cheloveka: tsennostno-mirovozzrencheskiy podkhod, Vestnik Mininskogo universiteta. 2017. №4. 27 s. DOI: https://doi.org/10.26795/2307-1281-2017-4-12

[20] A.N. Tatarko, A.A. Mironova, Ye.V. Maklasova, Individual'nyye tsennosti i aktivnost' ispol'zovaniya interneta: sopostavleniye Rossii i Yevropeyskikh stran, Sotsial'naya psikhologiya i obshchestvo. 2019. T. 10. . 4. S. 77-95. DOI: 10.17759/sps.2019100406. 